\title{
The Conservation Values Integration Model in Scientific Approach of Civics in College
}

\author{
Ruhadi $^{1}$, Didi Pramono ${ }^{2}$, Asep Purwo Yudi Utomo ${ }^{3}$, Isnarto ${ }^{4}$ \\ \{ruhadi@mail.unnes.ac.id ${ }^{1}$, didipramono@mail.unnes.ac.id², aseppyu@mail.unnes.ac.id ${ }^{3}$, \\ isnarto.math@mail.unnes.ac.id ${ }^{4}$ \\ Department of Politic and Civic Education, Universitas Negeri Semarang ${ }^{1}$, Department of Sociology and \\ Anthropology, Universitas Negeri Semarang ${ }^{2}$, Department of Indonesian Language and Literature, \\ Universitas Negeri Semarang ${ }^{3}$, Department of Mathematic, Universitas Negeri Semarang ${ }^{4}$
}

\begin{abstract}
This study aims to analyze the integration model of the scientific approach and conservation values in the learning of Civics. This study used descriptive qualitative approach. The research subjects were some Civics lecturers, and the object in this study was the learning of Civics itself. Learning of Civics really requires innovation, so that students are able to apply high order thinking skills and conservation values. The implementation of conservation values in the Civics is textually contained in the Semester Learning Plan (RPS) and is practiced in learning and evaluating learning outcomes. The conservation values are integrated in the scientific approach applied in the Civics classes. $43 \%$ of lecturers apply project-based learning models, $31 \%$ of lecturers apply problembased learning models, and $26 \%$ of lecturers apply discovery learning ones. In order to measure the extent to which the conservation values are applied by students, the lecturers need to apply authentic assessments.
\end{abstract}

Keywords: scientific approach, conservation value, civics.

\section{Introduction}

An Issue about disruption led to concerns about the character values decline of national culture. The challenges of the $21^{\text {st }}$ century requires deliberate effort to cultivate students' personal growth and the ability to fulfill social and global responsibilities [1]. Negative behavior that is very visible today is a world that loses the local wisdom of the people inside. People are too free to express utterances of hatred, slander, and hoaxes. Current technological developments enable anyone to access anything. This is what makes the problem increase more.

One field that has strategic value in maintaining the character values of national culture is through education. Law No. 20 of 2003 concerning the National Education System explains that "Education is a conscious and planned effort to create a learning atmosphere and learning process so that students actively develop their potential to have spiritual strength, self-control, personality, intelligence, noble character, and skills needed by, society, nation, country, and themselves." Obviously, the main goal of education is the development of national character. Education character is not a new idea. The idea of school implanting virtues is as old as schooling itself $[2,3]$.

When people first learn of moral or character education, their second question is typically 'Is this a new field?' (Their first question is 'What is that?') The answer is that this field has existed as long as humans have thought about how to raise each subsequent generation. 
This following of terms will be used and have been acumulated and defined by various sources one of which is character education refers to a curriculum that addresses helping students identify positive trait in them selves to help them make positive choice.that the students believe students in the school respect teachers both before lessons in character education and after. This suggests that student respect towards teachers is unchanged by character education, and perhaps, character education should focus more on student.

The characters that can be increased by education are: attitude of believe in God; respect for science; respect for other people; attitude of appreciating ourselves as imperferct human being; respect for humanities; critical thinking to convey of idea; handle thing carefully; work hard and have a passion to solve every problem; be discipline; responsible; and consistent [4]. Character building activities affect positively on positive behavior of students leading to recommendations for implementing character building $[5,6,7,8,9,10,11]$.

Education in the era of disruption and industrial revolution 4.0 requires massive innovation, as a defensive effort so that the character values of national culture are maintained. Teachers can use various methods to integrate character values in teaching learning processes $[11,12$, 13].

The primary effort in cultivating the values of national cultural character is through the Learning of Civics. This course is one of subjects studied at all levels, starting from elementary school, junior high school, high school to the university level. Through gradual and sustainable education, our country will have aware and educated generation. It is in accordance with the vision that higher education is developed and directed in order to:

1) Be a center of science, technology and art development and the center of research activities in accordance with the needs of the present and the future development.

2) Encourage students to master the knowledge of technology and the art sincerely and have a great sense of responsibility towards the future of the nation and state of Indonesia in the context of implementing the Tri Dharma of Higher Education.

3) Developing campus life management as a cultured, moral, and Pancasilaic people with Indonesian personality [14].

Civics is a group of PDC courses, it stands for Personality Development Courses. So that in colleges, this course is a source of value and guidance for conducting study programs in encouraging students to develop their personality as Indonesian people completely. Civics does not only teach "transfer of knowledge" but also "transfer of value", so that in this course, students are not only provided with knowledge that leads to intellectual intelligence but also is provided with the transfer of values to form moral and spiritual intelligence.

Character transcends religion and culture to serve the common good. "Its working assumption is that all of us possess an innate capacity for moral goodness; character resides within each of us, largely independent of the relationships we have or the communities into which we are born. These endowments only need to be coaxed out and developed within the personality." [15]. Children need guidance to be able to manifest good character. To develop moral citizens good character needs to be brought out by family and reinforced in community values [15].

Civics is concerned with three different elements: knowledge, skills and disposition. Civic knowledge refers to people understanding of how the political system works and of their own political and civic rights and responsibilities (e.g. the rights of freedom to express opinion and to vote and to run for public office, and the responsibilities to respect the rule of law and the rights and interests of others). Civic skills refer to people ability to analyze, evaluate, take and defend positions on public issues, and to use their knowledge to participate in civics and political processes (e.g. to monitor government performance, or mobilize other citizens around particular 
issues). Civic dispositions are defined as the citizen traits which are necessary for a democracy (e.g. tolerance, public spiritedness, civility, critical mindedness and willingness to listen, negotiate, and compromise) [16].

The learning approaches in Civics need to involve all human elements, including logic, psychology, and sociology. The approach that is relevant to these characteristics is the scientific approach (scientific approach). In scientific approach, the focus of learning is not only on learning completeness, but also on other things, namely skills and attitudes. The scientific approach aims to get students to know, understand various materials using scientific approach, and understand that material or information which does not only come from educators, but that the material or information can come anytime and anywhere.

Scientific learning consists of observing (to identify things that are itended to be known), formulating questions (and formulating hypotheses), trying or collecting data (information) with various techniques, associating or analyzing or processing data (information) and concluding and communicating the results which consist of conclusions to obtain knowledge, skills and attitude.

The reasons for using scientific approach lie on the need of a learning process to be guided by scientific rules. The scientific approach is intended to provide understanding to students in recognizing and understanding various materials using the approach. The information can come from anywhere, anytime, and does not depend on the information provided by the lecturer. Students are directed to actively seek information from various sources. The lecturer is only a guide and facilitator in lectures. The application of the scientific approach in learning will make students actively find information from various sources themselves. These information can be received by reading, experimenting, asking questions, and listening.

This article specifically discusses the integration model of the scientific approach and conservation values in the learning of Civics, such as what models are applied, at what points these values are inserted, and the evaluation mechanism applied to measure the extent to which the implementation of the model is successful.

\section{Methods}

The methods used in this study were observation, interviews, survey questionnaires, with a descriptive qualitative approach. The research subjects were the Civics lecturers, and the object in this study was the learning of Civics itself. The data use triangulation techniques, and the use descriptive qualitative techniques as the analysis techniques.

\section{Results and Discussion}

Civics is a subject that is used as a means for developing and preserving noble values and morals rooted in Indonesian national culture [17]. Civics is essentially a subject that can shape the personality of students because this course discusses about how a person becomes a good citizen. A good citizen is a complete Indonesian human being who is not only a resident or born in Indonesia or an Indonesian citizen, but a complete Indonesian human being is an Indonesian human who has the spirit of Pancasila, and is able to practice it in daily life.

Based on the results of repeated observations over 4 semesters regarding the application of scientific approaches in 50 Civics classes, the following data are obtained 
Table 1. Average Values of Civics Before Applying the Scientific Approach

\begin{tabular}{lll}
\hline Semeter & Total Clas & Average \\
\hline Gasal 2016/2017 & 50 & 79.50 \\
Genap 2016/2017 & 50 & 80.60 \\
\hline
\end{tabular}

Table 1. Average Values of Civics After Applying the Scientific Approach

\begin{tabular}{lll}
\hline Semeter & Total Clas & Average \\
\hline Gasal 2017/2018 & 50 & 81.75 \\
Genap 2017/2018 & 50 & 85.75 \\
\hline
\end{tabular}

Based on the data above, it can be explained that there is a significant influence on the results of the value of Civic Education before applying the scientific approach and after applying the scientific method in Civic Education. This shows that, Character Education which is integrated in the curriculum in Higher Education is a strategic step in instilling character in students especially towards values that are based on Pancasila in encouraging the realization of Pancasila democracy.

Citizenship Education in Indonesia when compared with Citizenship Education in America it has a different orientation to the character values that are developed. Character education in America further develops the values of liberal democracy, while Citizenship Education in Indonesia integrates the values of Pancasila Democracy, especially the practice of social cultural conservation values. Traditional citizenship education (typically self-identified as 'civic education') has employed the knowledge model. In the civics courses required in US middle and especially high school curricula the focus is on factual knowledge about government, as well as on the individual as the bearer of constitutional rights. In this context, the Center for Civic Education 'designer of the CIVITAS (the great bulk of which focuses on government, the constitution and elections) has had particular impact in promoting civics approaches. It has been the architect for national standards on what students need to know, and its school curriculum, 'We the People' (as well as its authorized international version, 'Project Citizen') is widely used' [18].

Civics leads to two aspects. First, as an educational input to provide knowledge and academic experience, professional skills, intellectual acuity and depth, obedience to values or the principles of it. Second, as an educational input to form a personality or identity of a scientist who is committed to the vision of the nation (it is matter of being).

Civics has important and strategic values in preparing superior, reliable and moral human resources since early age. Moral values play an important role in motivating civic action because they make a sense of purpose for civic action. It is evident that this profile of engagement is only partially accountable in terms of knowledge [19].

The success of students in college in the learning process is not only determined by good teaching staffs or a solid curriculum but also determined by the learning model used by lecturers in the classroom. The teaching method can excite and gain students' interest and motivation to study. Various models of teaching have been developed by experts in the form of group learning, independent study, field studies and others. The models or methods of teaching require students to perform activities which are suitable with high development of students. Thus, students are expected to be able to learn independently and carry out learning activities without depending much on the teacher [20].

Character building can be integrated in all subjects and the process of teaching and learning. Therefore, the teachers should prepare character building starting from planning, acting, and 
evaluating. Character building integrated in the proces of teaching and learning can be conducted in preliminary, core, and closing activities. Integration of character building in core activities of the teaching and learning process can be conducted in exploration, elaboration, and confirmation activities.

Civics learning really needs innovation, so students can apply high order thinking skills, master the material better, learn more fun, and conservation values can be more internalized by students. Implementation of conservation values in the Civics textual course contained in the Semester Learning Plan (RPS), it is practiced in learning and evaluating learning outcomes. Data shows that lecturers have applied various innovative learning models, including:

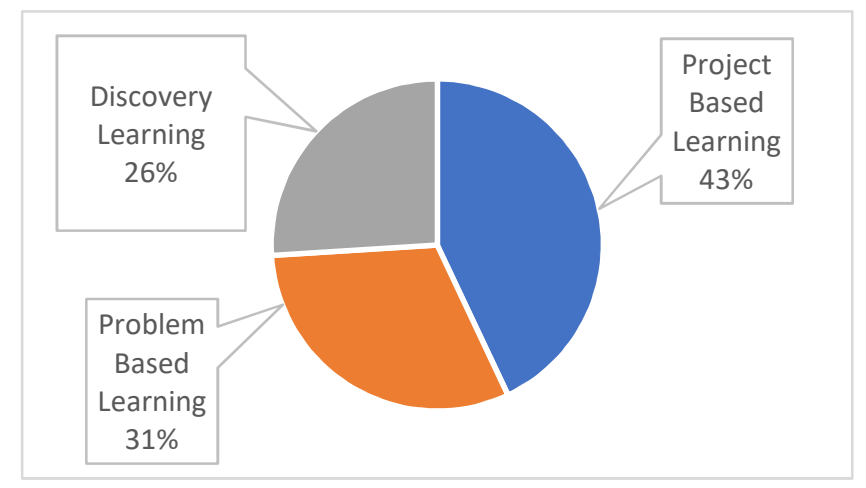

Fig. 1. Various Innovative Learning Models

Data in figure 1 shows that $43 \%$ of lecturers apply project-based learning, $31 \%$ of lecturers apply problem-based learning models, and $26 \%$ of lecturers apply discovery learning models. That is, Civics has been implemented in accordance with the scientific approach. Project Based Learning $(\mathrm{PjBL})$ is an integrated learning approach and activities and also real tasks that have brought challenges for students to solve. These activities generally reflect the types of learning and work people do in everyday life outside of the classroom. PjBL is generally done by groups of students working together with the common goal [21].

PjBL teaches students not just about the content, but also important skills in ways students have to be able to behave maturely in society. These skills include communication and presentation skills, organization and time management skills, research and inquiry skills, selfassessment and reflection skills, group participation and leadership skills, and critical thinking [21].

Performance is assessed on an individual basis, and takes into account the quality of the product produced, the depth of content understanding demonstrated, and the contributions made to the ongoing process of project realization. PjBL allows students to reflect upon their own ideas and opinions, and make decisions that affect project outcomes and the learning process in general. The final product results in high-quality, authentic products and presentations [21].

In the project based learning $(\mathrm{PjBL})$ model students are directed to explore, evaluate, interpret, synthesize, and inform to produce various forms of learning outcomes. The activities start from designing questions, arranging project plans, arranging schedules, conducting monitoring, testing results and evaluating student learning experiences.

Problem-Based Learning (PBL) is a non-traditional teaching technique where "the problem drives the learning" [22]. First, a problem is presented. Students have to then search for the information needed to help them to solve it [23]. In PBL,"learning is student-centered" [22] and 
the instructor role is not lecturing, as in the traditional style of teaching that has dominated engineering and science education, but coaching the students to acquire knowledge and to become "self-directed learners" [24].

PBL is focused, experiential learning organized around the investigation, explanation, and resolution of meaningful problems $[25,26,27]$. In PBL, students work in small collaborative groups and learn what they need to know in order to solve a problem. The teacher acts as a facilitator to guide student in learning [27].

The problem-based learning (PBL) directs students to be able to solve problems in the real world, even to initiate the alternative solutions. Learning activities begin from student orientation to problems, students organizations, guided individual and group investigations, field findings development and presentation, analysis and evaluation of problem solving processes.

Discovery learning (DL) model is learning theory which is defined as a learning process that occurs when students are not presented with lessons in their final form, but it is expected that students organize themselves. Discovery Learning has the same principles as inquiry and Problem Solving. There are no principal differences in these three terms, Discovery Learning emphasizes the discovery of previously unknown concepts or principles. The difference with discovery is that the discovery of problems faced by students is a kind of problem made up by the teacher. The teacher has to give students the opportunity to become a problem solver, a scientist, historian, or mathematician. Teaching materials are not presented in the final form, but students are required to carry out various activities to gather information, compare, categorize, analyze, integrate, reorganize materials and make conclusions [28].

Discovery learning model directs students to learn actively, organize, and find concepts or principles that have not been previously known. This learning activity starts from preparation, implementation (simulation), problem identification (problem statement), data collection, data verification, generalization.

Integrated conservation values start from RPS, in the scientific approach applied in learning Civics, until the evaluation of learning. Conservation values in RPS are found in Graduate Learning Outcome (CPL), which are then translated into Course Learning Outcome (CPMK). These achievements are realized through lecture activities, both in class and outside the classroom. Take one example, if CPL in the RPS for Civics is written "Graduates of this course are expected to be able to: internalize conservation values in learning". This CPL is translated into CPMK to,

After attending this lecture students are able to:

a. Analyze contextual issues of Civics, develop positive attitudes and behave well that support the spirit of nationality and love for the country based on conservation values.

b. Be concerned about the survival of the community, nation and state in the Unitary State of the Republic of Indonesia with the principle of conservation values.

c. Analyze contextual issues of Civics, develop positive attitudes and behave appropriately supporting civil democracy with the principle of conservation values.

d. Analyze contextual issues of Civics, develop positive attitudes and behave appropriately supporting legal awareness and diversity with the principle of conservation values.

The learning activities carried out by lecturers certainly have to refer to the CPL and CPMK, about how to achieve the CPL and CPMK. In Civics learning with scientific approach, the focus of learning is not only on learning completeness, but also on other things, namely skills and attitudes. The scientific approach aims to get students to know, understand various materials 
using a scientific approach, and understand that material or information does not only come from educators but that the material or information can come anytime and anywhere.

Scientific learning consists of observing (to identify things that want to be known), formulating questions (and formulating hypotheses), trying or collecting data (information) with various techniques, associating or analyzing or processing data (information) and interesting conclusions and communicating the results which consist of conclusions to obtain knowledge, skills and attitudes.

The reasons for using scientific approach lie on the need of a learning process to be guided by scientific rules. The scientific approach is intended to provide understanding to students in recognizing and understanding various materials using the approach. The information can come from anywhere, anytime, and does not depend on the information provided by the lecturer. Students are directed to actively seek information from various sources. The lecturer is only a guide and facilitator in lectures. The application of the scientific approach in learning will make students actively find information from various sources themselves. These information can be received by reading, experimenting, asking questions, and listening.

The university declared as a campus with the character of conservation is Semarang State University (UNNES). UNNES vision of "Becoming a Conservation and International-reputed University" is very strategic and becomes the main reference in the implementation of education. In this case, it relates to the application of eight character conservation values into lectures activity, especially in Civics course. The eight conservation characteristics include inspirational, humanistic, caring, innovative, sporty, creative, honest and fair values. Planting 8 characters of conservation is very directly proportional to the main goal of Civics in the formation of national character, in order to be good citizens.

In order to measure CPL and CPMK, the lecturer needs to apply authentic assessment (authentic assessment), including project assessment, performance assessment, portfolio assessment, and written tests. Authentic assessment describes multiple forms of assessment that reflect student learning, achievement, motivation, and attitude on instructional relevant classroom activities [29]. Authentic assessment as an assessment requiring students to use the same competencies, or combinations of knowledge, skills, and attitudes that they need to apply to the situation in professional life [30].

Authentic assessment is important because of some reasons: (a) Increasing concerns among educators and students about the lack of alignment between stated curriculum objectives emphasising the development of professional capacities and assessments tasks lacking relevance to those proposed learning outcomes; (b) The need for teaching and learning experiences to develop knowledge and skills on one hand, and supportive attitudes and values on the other hand to graduate informed, well-rounded and productive workers and citizens; and (c) Educators' need to teach their courses more effectively by using appropriately self-and peerassessment strategies to share judgment making on the quality of student work among key parties in the educational process [31].

Project appraisal is carried out through collaborative field assignments. Students are directed to explore real problems that occur in the field, related to the lecture material presented on Civics such as Human Rights, Nation and State, National Defense, National Identity, Democracy, Regional Autonomy, Archipelago Insight, National Resilience, and National Politics and Strategy. The results of this field observation were then presented or communicated in a class discussion forum.

Lecturers in this forum can conduct performance assessments. Students who are active in discussions and supported by worth discussion material will certainly get high rating points. In addition, through discussions, lecturers can see students who are enthusiastic with the lectures, 
students who master the material well, and students who really do the assignments or projects properly and correctly. The lecturers observation results in this discussion forum were recorded in the assessment instruments that had been developed previously, so that the principles of authentic assessment were actually carried out by the lecturers in learning.

In addition to the two previous assessments, there are also several lecturers who implement portfolio assessments. Students archive all assignments given by the lecturer, in time they will be asked again by the lecturer for portfolio assessment. This mechanism is effective for observing the development of the students' learning.

The Civics course ends with the Final Semester Examination (UAS) simultaneously, through written assessment. Students are directed to be able to express their ideas and critical analysis in writing on the test answer sheet. Through this mechanism lecturers can get an overview of student competencies at the end of the semester. Of course, competencies are in accordance with the CPL and CPMK that have been previously set in the RPS.

\section{Conclusion}

Civics course is in line with UNNES vision as a conservation-minded campus. In order to achieve this vision, learning innovations are indispensable, including to use the integration model of conservation values in the scientific approach to learn Civics. The scientific approach makes students able to develop high order thinking skills, critical thinking, communicative, collaborative, and creative. This competency is the demand for education in 21 st Century, which has been outlined in the Semester Learning Plan. These competencies can be evaluated through authentic assessment, including project appraisal, performance assessment, portfolio assessment, and written tests. 


\section{References}

[1] Bialik, Maya, Michael Bogan, Charles Fadel, and Michaela Horvathova. (2015). Character Education for the 21 st Century: What Should Students Learn? Center for Curriculum Redesign: Boston, Massachusetts.

[2] O'Sullivan, S. (2004). Books to Live by: Using Children's Literature for Character Education. Reading Teacher, 57(7), 640-645.

[3] Agboola, Alex and Kaun Chen Tsai. (2012). Bring Character Education into Classroom. European Journal of Educational Researc. Vol. 1, No. 2, 163-170. ISSN 2165-8714.

[4] Dwirahayu, Gelar. (2011). Implementation Of Character-Building Education In Mathematics Teaching And Learning To Create Of Human Character. Proceeding at International Seminar and the Fourth National Conference on Mathematics Education 2011 "Building the Nation Character through Humanistic Mathematics Education". Department of Mathematics Education, Yogyakarta State University, Yogyakarta, July 21-23 2011.

[5] Dodds, D. M. (2016). The effects of character education on social-emotional behavior.

[6] Montonye, M., Butenhoff, S., \& Krinke, S. (2013). The influence of character education on positive behavior in the classroom.

[7] Patella, C. (2003). The effect of character education on student behavior.

[8] Branson, C. (2004). Effects of character education on student behavior.7-14.

[9] Althof, W., \& Berkowitz*, M. W. (2006). Moral education and character education: Their relationship and roles in citizenship education. Journal of moral education, 35(4), 495-518.

[10] Thompson, W. G. (2012). The Effects of Character Education on Student Behavior. Electronic Theses and Dissertations. Paper 706. Htttp://dc.etsu.edu/etd/706.

[11] Marini, Arita. (2017). Character Building Through Teaching Learning Process: Lesson In Indonesia. Ponte: International Journal of Sciences and Research. Vol. 73 | No. 5 | May 2017.

[12] Milson, A. J. \& Mehlig, L. M. 2002. Elementary School Teachers' Sense of Efficacy for Character Education. The Journal of Educational Research, 96(1), 47-53.

[13] Hadi, R. 2015. The Integration of Character Values in the Teaching of Economics: A Case of Selected High Schools in Banjarmasin. Indonesia: Universitas Lambung Mangkurat. doi: 10.5539/ies.v8n7p11.

[14] Sunarto. (2015). Pendidikan Kewarganegaraan di Perguruan Tinggi. Semarang: UNNES Pers.

[15] Hunter. (2000). Civics Education in America. Civicus: USA.

[16] Rietbergen, Jennifer, and McCracken. (2018). Civic Education. Civicus: USA.

[17] Susanto, Ahmad. (2012). Teori Belajar dan Pembelajaran di Sekolah Dasar. Jakarta: Kencana Prenada media Group.

[18] Boyte, Harry C. (2003). Civic Education and the New American Patriotism Post-9/11, Cambridge Journal of Education, 33:1, 85-100.

[19] Carretero, Mario, Helen Hazte, and Angela Bermudez. (2015). Civic Education. researchgate.net. [20] Elida Prayitno. (1989). Motivasi dalam Belajar. Jakarta: Depdikbud Dirjendikti PPLPTK.

[21] Goodman, Brandon and Stivers. (2010). Project Based Learning. ESPY 505. Educational Psychology.

[22] Tse, W., \& Chan, W. (2003). Application of Problem-Based Learning in an Engineering Course. International Journal of Engineering Education, 19( 5), 747-753. Retrieved from https://www.ijee.ie/articles/Vol19-5/IJEE1440.pdf.

[23] Salas, J., Segundo, J., Álvarez, C., Arellano, J., \& Pérez, A. (2014). Evaluation of the Use of Two Teaching Techniques in Engineering. International Journal Of Engineering Pedagogy (Ijep), 4(3), 4. http://dx.doi.org/10.3991/ijep.v4i3.3287.

[24] Forcael, E., González, V., Orozco, F., Opazo, A., Suazo, Á., \& Aránguiz, P. (2015). Application of Problem-Based Learning to Teaching the Critical Path Method. Journal Of Professional Issues. In Engineering Education And Practice, 141(3), 04014016. http://dx.doi.org/10.1061/(asce)ei.19435541.0000236

[25] Barrows, H. S. (2000). Problem-Based Learning Applied to Medical Education, Southern Illinois University Press, Springfield. 
[26] Torp, L., and Sage, S. (2002). Problems as Possibilities: Problem-Based Learning for K-12 Education, 2nd edn., ASCD, Alexandria, VA.

[27] Cindy E. Hmelo-Silver. (2004). Problem-Based Learning: What and How Do Students Learn? Educational Psychology Review, Vol. 16, No. 3, September 2004.

[28] Curriculum Socialization Material-Ministry of Education and Culture, 2013

[29] O'Malley, J. Michael and Lorraine Valdez Pierce. (2013). From Authentic Assessment for English Language Learners: Practical Approaches for Teachers. Indiana Department of Education. Office of English Language Learning and Migrant Education.

[30] Gulikers, J., Bastiaens, T., \& Kirschner, P. (2004). A five-dimensional framework for authentic assessment. Educational Technology Research and Development, 52 (3), 67-85.

[31] Mueller, J. (2006). Authentic assessment toolbox. Retrieved on 25 June from the website: http://jonathan.mueller.faculty.noctrl.edu/toolbox/whatisit.htm\#looklike 